A Balaton déli partján a mester-

séges apadási övön áll az épület

\title{
BALATON-PARTI VILLA
}

\section{Időutazás a svájci villáktól a mediterrán házig}

É pít és z:

Csikós Mihály
Tavasz van, lassan ismét kinyílnak a tóparti villák. Útközben egymás után suhannak el a napfényben fürdőző nyaralóházak a vasúti kocsi ablakában. Eltérő korok heterogén emlékei torlódnak össze a Balaton déli partján utazva: decens nagypolgári villák, naivan historizáló vagy filigrán modern víkendházak, típusépületek és barkácsolt kunyhók sorakoznak egymás mellett. A Metszet jelen lapszámában tárgyalt két Balaton-parti nyaraló párhuzamos történetként is olvasható. A tájegységi népiurbánus probléma mellett a polgári villaépitészet karaktere is folyamatosan napirenden lévő kérdés a régió rekreációs célú épités történetében. A siófoki villa kapcsán érdemes feltárnunk, hol keressük a balatoni villaépítészet kiindulását? A városias épitészettel szemben milyen alternativát jelenthet a fesztelen tóparti környezet és mindez milyen hatással van a forma- és részletképzésre? A Balaton régiót jellemző stíluspluralizmus már a huszadik század első felében megérintette az épitészeket, akik a helyi fürdőegyesületek, civil szervezetek bázisán önkéntes mozgalmakat szerveztek az általuk harmonikusnak tekintett balatoni településkép és épitészeti stílus megteremtésére. A balatoni villa és nyaraló mint a modernitás prototípusai előképek nélküli új feladatot jelentettek az építészetben, nemcsak a Balaton, de a nemzetközi vizek partvidékén is. [1] A Balaton-parti fürdo”kultúra érdemben csak az 1860-as évek után kezdett el kibontakozni, amikor a déli vasutat kiépítették Budapest és Fiume között, a Balaton déli partját is érintve.

A modernitás szimbólumaként is felfogható vasút a dinamikusan fejlődő nagyvárossal kötötte össze a régiót, és a nyaralás egy új életformájának a lehetőségét is megteremtette a tóparton, bár erre nemcsak a fejlődő mobilitás, hanem a vasútvonal épitéstechnológiája is hatással volt. [2] Az 1861-ben kiépített vonalat ugyanis néhány év múlva elmosta a Balaton ingadozó vízszintje, így a siófoki zsilip fejlesztésével két métert apasztottak a 
vízszintből, ezzel biztosítva a zavartalan vasútforgalmat. A vízszintsüllyesztés nyomán egy új parti sáv került szárazra, amely talajminősége miatt mezőgazdálkodásra, legeltetésre nem igazán volt alkalmas, a vasútnak is köszönhetően éledező turizmus azonban új lehetőségeket hordozott magában. Az egységes területfejlesztést erősítette, hogy nem aprózódott el a tó körül körbefutó úgynevezett apadási öv, hanem a tóparti nagy földesurak, a Széchenyiek, a Hunyadiak, Jankovichok kezébe került, akik egységesen értékesíthették azt. Ezen az övön morfológiai és topográfiai kötöttségektől mentesen alakulhattak ki az új fürdőtelepek, az ősközségektől teljesen függetlenül.

Siófokon a földrajzi adottságoknak köszönhetően a kereskedelem is fontos tényezőt jelentett, az első nyaralópolgárok közt számos kereskedőt is találhatunk. A 19. század végére már egyre több fürdőtelep épült ki, más és más célközönséggel és építési felfogással. Siófok fejlődésében az építtetők révén azonban már ekkor megjelent a modernitás karaktere, a tópart első modern villasora is itt épült. Közben Balatonföldváron a nagypolgárság, az arisztokrácia építkezett, Szemesen, Bogláron, Bélatelepen a tehetősebb középosztály. Mivel a nyaralóépítészet és a nyaralótelep kialakítása is előkép nélküli feladatnak számított, az első házak a külföldi, elsősorban alpesi üdülőhelyek felfogását tükrözték. Az úgynevezett „svájci villák” fa díszítő szerkezeteikkel, tornácaikkal a kedvelt hegyvidéki emlékeket idézték vissza csak rövidebb utazással, a Balaton-parton.

A villák reprezentatív kialakítása a városi épületekkel volt egyenértékü, mind a szerkezeti, mind a funkcionális szempontokat tekintetbe véve. A falvastagságok, nyílászárók, födémszerkezetek jellemzőivel, valamint a cselédszobákkal, vendégszobákkal, tágas reprezentatív helyiségekkel megtervezett épületek az egész éves tartózkodást is lehetővé tették volna, bár a tulajdonosok csak két hó- napos lent tartózkodásra használták valójában. A Trianon után tradicionális fürdőhelyeit elvesztő, bezárt országban felértékelődött a Balaton-part. Újabb és újabb társadalmi rétegek előtt nyílt meg a saját nyaraló építésének lehetősége, bár a gazdasági válságok szorításában egyre kevesebb anyagi teherviselo képességgel. Az expanzív módon felparcellázott Balaton-parton egyre zavarosabb összképet mutattak a különböző felfogásban épült nyaralóházak. A megoldás keresésében Kotsis Iván vállalt fontos szerepet, aki mintaterveket dolgozott ki az építtetőknek. [3] Kotsis nemcsak a népi építészet másolását, de a történeti formákat is elutasította. Számára az egyszerüség jelentette a kiindulást: a nagypolgári „svájci" villák nehézkes stílusával és költséges megépítésével szemben inkább a nyaralás szezonális, könnyed modern felfogására helyezte a hangsúlyt. A klimatikus megfontolások alapján alacsony hajlású tetővel, verandával, zsalugáterrel dolgozta ki ajánlati terveit, a homlokzatokra csak pasztellszínú vakolatot javasolt, tagozatok nélkül. A belső terekben is ezt az egyszerú karaktert vitte tovább, minél praktikusabb elrendezéssel, csak a legszükségesebb helyiségekkel, hálókamrákkal és bútorzattal. [4] Kotsis személyes érdeklődése és tanulmányútjai révén formálásában olaszos karakter jelent meg, amely aztán a mintatervek népszerüségének köszönhetően gyorsan elterjedt a harmincas évek újonnan épített üdülőtelepein. Igaz, ezek az épületek csak a két hónapos nyári időtöltés kielégítésére összpontosítottak, a szerkezetek nem rendelkeztek megfelelő hőszigetelő képességgel a téli használathoz.

Egyszerüség, játékosság és kísérletező formálás jellemezte a hatvanas évek nyaralóépítészetét. A nyaralás természetközeli felfogása ebben az időszakban artikulálódott legtisztábban. A forradalom utáni társadalmi konszolidációban egyre szélesebb rétegek jelentek meg a tóparton, akiknek egyre szúkebb telkeken, egyre kisebb

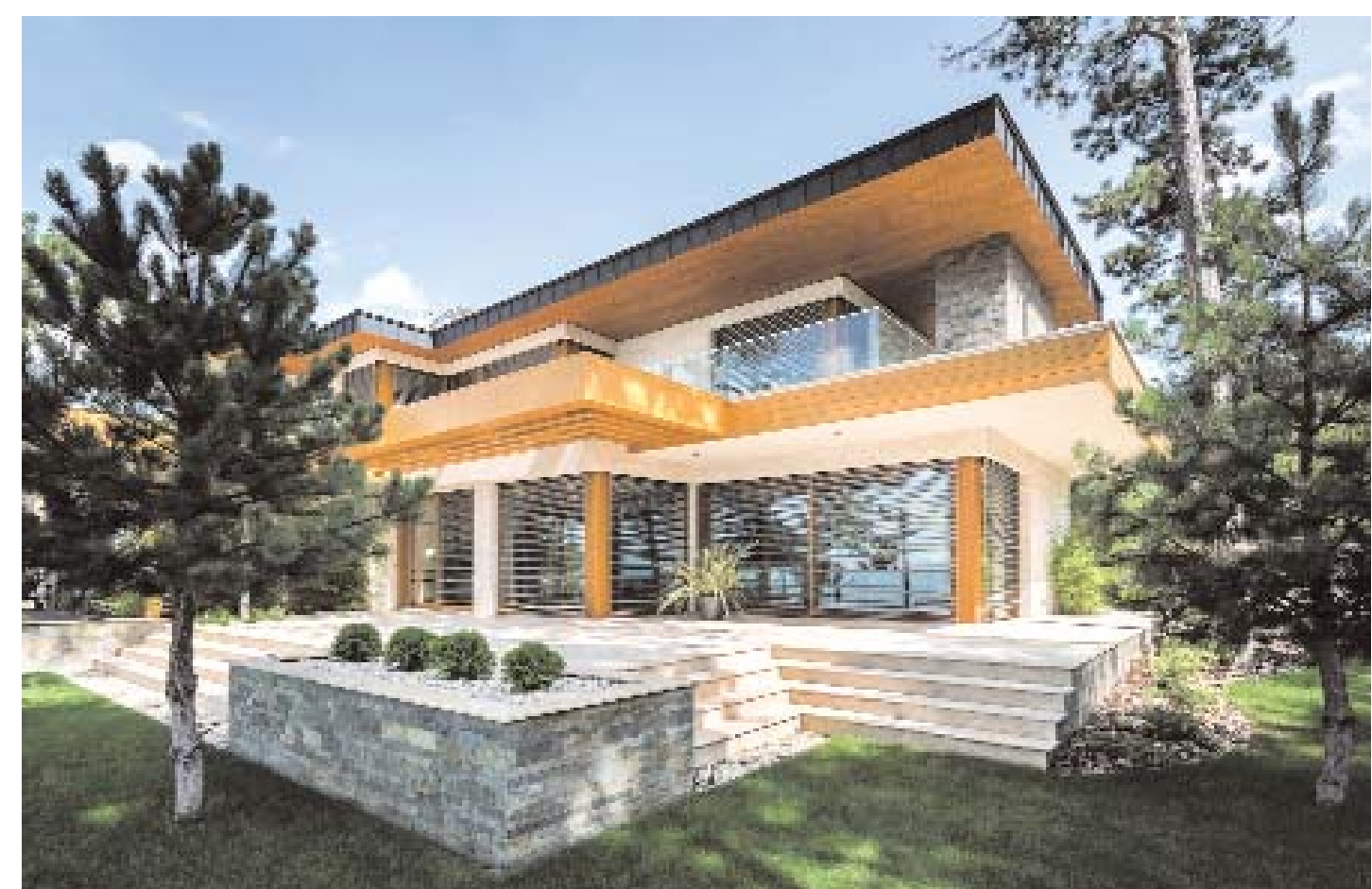

A déli part jellegzetes, telepített fenyveseibe ágyazott mediterrán tömegforma 
Részletképzés: a rétegzett burkolati rendszereket a mai hőszigetelési követelmények is szükségessé teszik
Az alaprajzi térszervezés a családi házakkal egyenértékủ kialakítású
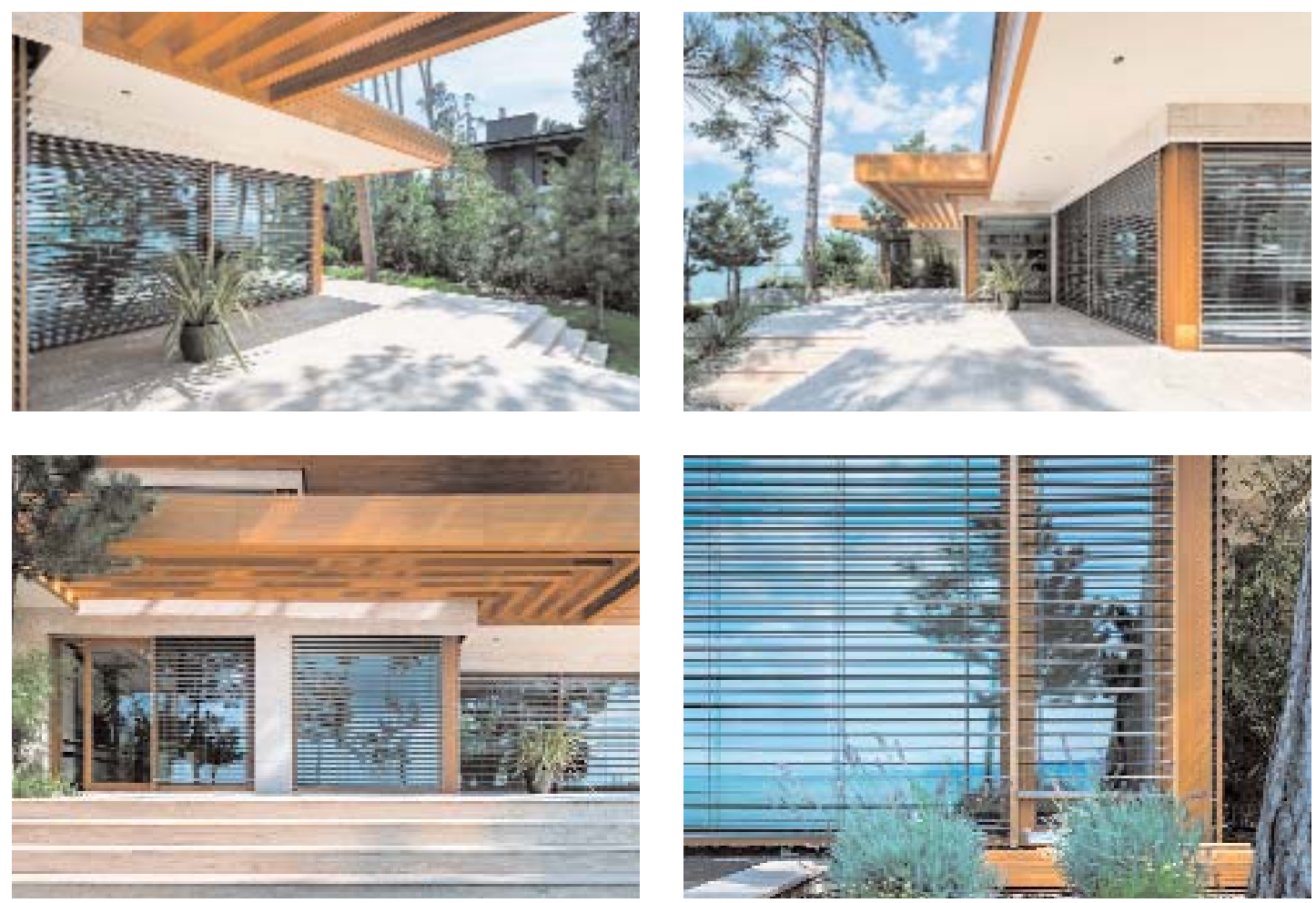

hétvégi ház építésére nyílt lehetőségük. [5] A sokszor saját kezűleg felépített épületek minősége rendkívül alacsony volt, a Balaton-környéki Fóépítészség és a Típustervező Intézet Callmeyer Ferenc koordinálásával típustervsorozatokat bocsátott ki a balatoni településkép egységes rendezésére. [6] A kor neves építészei által terve- zett típusok a nyaralás minimális térigényére helyezték a hangsúlyt, és a nagyvárosi életformával szemben a nomád, természetközeli élet alternatíváját kínálták. Az épíesetben kísérletező konstrukciók az építészszakma számára is a gondolkodást megtermékenyíto, az építészetet tészeti formálás archetípusait megidéző, könnyed, sok

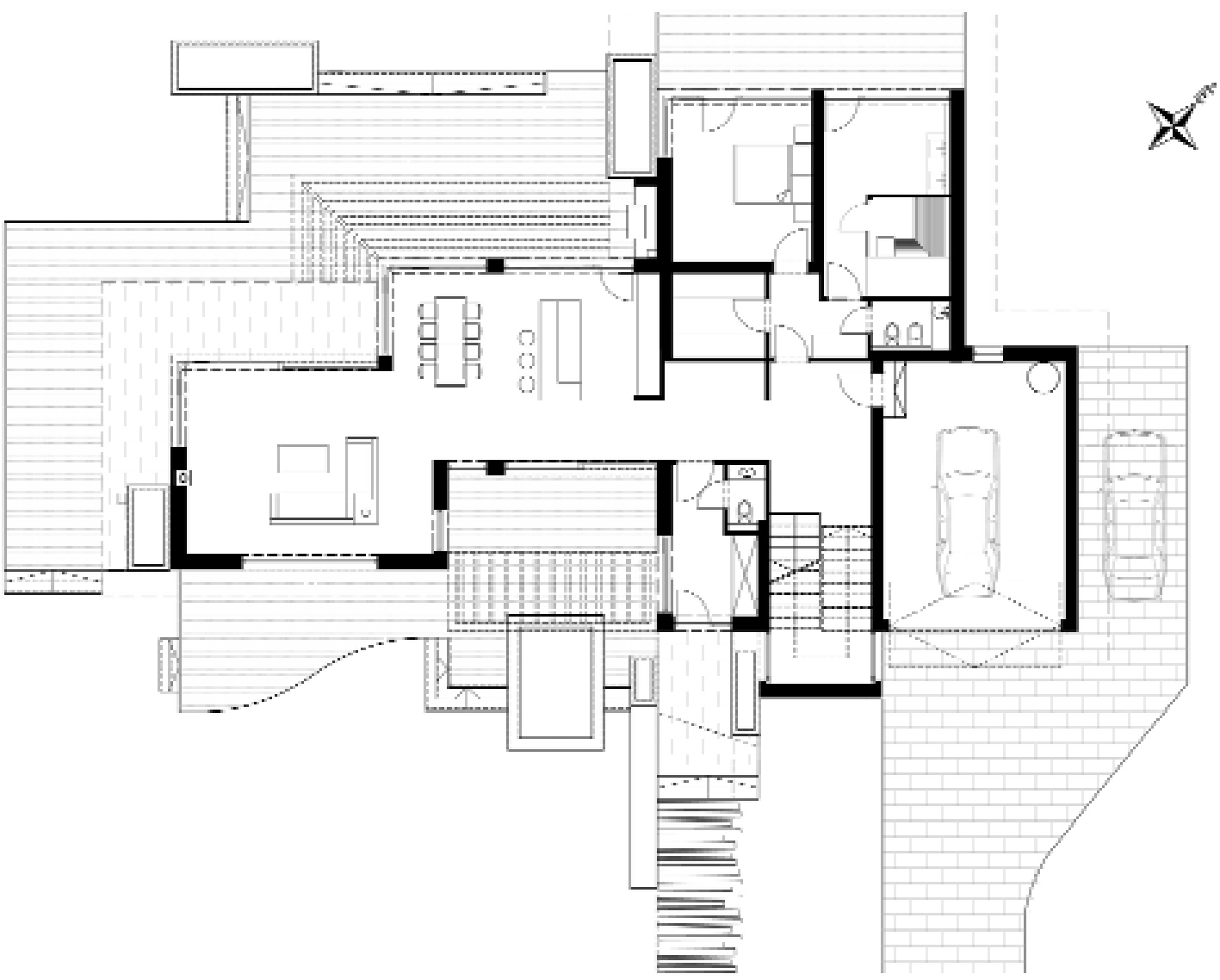




\section{$\mathrm{A}$}

\section{SUGÁR, Péter: THE POETICS OF PRACTICE} Citation: Metszet, Vol 10, No 2 (2019), pp 14-21, DOI: 10.33268/Met.2019.2.1 JAZZ LOFT AQUINCUM APARTMENTS, ÓBUDA, HUNGARY

\section{ARCHITECTS - GÁBOR TURÁNYI and BENCE TURÁNYI}

Covering a period of almost thirteen years involvement with this project father and son architects have worked to find a fitting harmony between the old and new. Taking a long abandoned redbrick industrial building and completing the theme of brick construction to the exterior whilst inserting a contemporary reinforced concrete interior enforces these ideas. The metal cladding used on the exterior to roofs and balconies helps to offset the brickwork and confirm the design philosophy of this architectural practice.

\section{AMICHAY, Eva: PAWSON IN JAFFA} Citation: Metszet, Vol 10, № 2 (2019), pp 22-25, DOI: 10.33268/Met.2019.2.2 THE JAFFA HOTEL AND RESIDENCES, TEL-AVIV, ISRAEL

ARCHITECT - JOHN PAWSON

In Tel-Aviv, The City That Never Sleeps, how does one create a place to relax in relative calm? A former convent and hospital has been refurbished, including careful restoration of archaeological structures to create a new spatial character via the com bined use of historical and contemporary furnishing and installations.

\section{WARE-NAGY, Orsolya: CAREFUL EXTRAVAGANCE} Citation: Metszet, Vol 10, No 2 (2019), pp 26-29, DOI: 10.33268/Met.2019.2.3 ONE ROOM HOTEL, ANTWERP, BELGIUM

ARCHITECTS - DRIESEN, VERSCHUEREN and DEBAETS (DMVA)

It would have been reasonable to take this tiny house, dating back to the 17th century, and simply restore it as a conventional dwelling, instead the client opted to explore new concepts in tourist accommodation. Taking all parts of the structure, both new and old, then painting them white (excluding the floors and entrance door) creates a clean aesthetic suited to short term rentals. This project offers a temporary place of stay to people who wish they had done a similar project but never got around to it.

\section{SEBES, Péter: THE AESTHETICS OF CENSORSHIP}

\section{Citation: Metszet, Vol 10, No 2 (2019), pp 30-33, DOI: 10.33268/Met.2019.2.4} HABITAT OF ORPHAN GIRLS, KHANSAR, IRAN

\section{ARCHITECTS - ZAV ARCHITECTS}

There is thought to be 140 million orphans world wide, these citizens have a right to a home and personal identity. This project in Khansar does just that by providing shelter and a true sense of "persian" cultural status. Respecting Iranian traditional laws this building has balconies covered in hijab-like textile awnings which provide the occupants with a sense of privacy and cultural inclusion. Otherwise this project does not attempt any form of grand architectural statement being constructed from locally sourced materials, following in the tradition of an atrium house with a water feature in the garden.

\section{WETTSTEIN, Domonkos: FOLK-URBAN DECONSTRUCTION} Citation: Metszet, Vol 10, No 2 (2019), pp 34-37, DOI: 10.33268/Met.2019.2.5 PORTUSHOME GUEST HOUSE, KISDÖRGICSE, HUNGARY

ARCHITECT - BARNA KOVÁCS D.

Should Folklore dictate how an architect designs a building or not? Maybe it is time to deconstruct the idea that traditional techniques can only apply to certain building types or locations. This guest house combines contemporary ideas of comfort and spatial arrangement with traditional, regional, construction skills. The resulting building establishes a new, yet, recognisable typology without falling victim to sentimentality.

\section{WESSELÉNYI-Garay, Andor: EMBROIDERED ARCHITECTURE} Citation: Metszet, Vol 10, № 2 (2019), pp 38-43, DOI: 10.33268/Met.2019.2.6 FAMILY HOME, NAGYKOVÁCSI, HUNGARY ARCHITECT - SZABOLCS DIENES DLA

Modernism questioned the idea of architectural decoration by drawing comparisons to embroidered cushions. Now we live in an age where decoration, although not obviously functional, can be viewed as architectural. This new form of architectural embroidery or embellishment brings with it another sense of worth that reinforces ideas of architectural wealth through visual creativity. Patterned brickwork, stone walls and decorative finishes to metal sheet and concrete all work together to create an architectural entity.

\section{WETTSTEIN, Domonkos: BALATON VILLA}

\section{Citation: Metszet, Vol 10, № 2 (2019), pp 44-47, DOI: 10.33268/Met.2019.2.7}

\section{VILLA AT LAKE BALATON, SIÓFOK, HUNGARY}

ARCHITECT - MIHÁLY CSIKÓS

Traditionally homes found on the bank of Lake Balaton served as summer season only holiday destinations. Now, due to changes in transportation, work-life variations this location is now being sought for all year round living. The question being how to establish a home which serves equally well throughout the year, a more urban typology or a Mediterranean feel?

\section{TARl, Gábor: CAPTIVATED BY WHITE Citation: Metszet, Vol 10, № 2 (2019), pp 48-51, DOl: 10.33268/Met.2019.2.8} COLOUR AND ARCHITECTURE AN INTERNATIONAL COMPARISON

ARTICLE BY - Dr. GÁBOR TARI

The question of why so many buildings are finished in white render has been investigated by Dr Tari in order to assess why colour schemes in architecture seem to be limited. Naturally this research touches on the united subjects of form, colour and texture linked to social factors of wealth and building use types. Sadly the result of his work demonstrates that, although seemingly natural materials (brick, stone, wood ) are thought of as being valid for construction, plaster renders usually end up being white or beige due to a lack of colour identity being recognised at an urban planning level. Meanwhile, once colours are used a sense of visual wealth is attained, although pastel tones are preferred.

\section{MEDGYASSZAY, Péter: A „SUSTAINABLE HOUSE"}

\section{Citation: Metszet, Vol 10, No 2 (2019), pp 52-55, DOl: 10.33268/Met.2019.2.8} REFURBISHMENT OF A LISTED DWELLING HOUSE

ARCHITECT - PÉTER MEDGYASSZAY

Ten years after the complete restoration of a listed dwelling house architect Péter Medgyasszay assess progress in terms of construction technology and environmental impact. Amongst his conclusions issues of problems regarding securing thermal insulation, waterproofing and thermal performance have been examined. From an energy point of view this project has been successful despite some technical problems. Current technologies, not available ten years ago, would also benefit this project type. 